
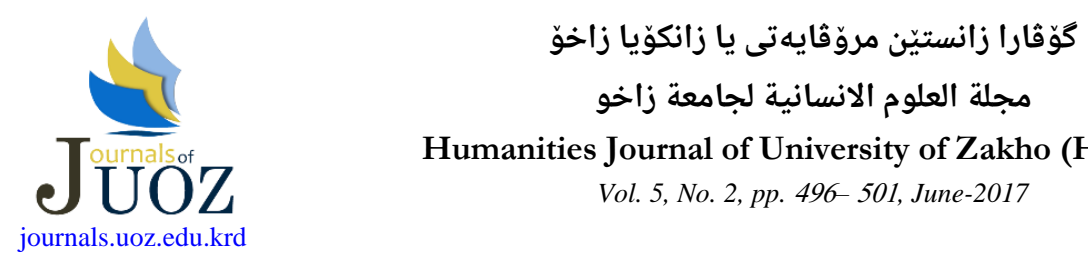

Humanities Journal of University of Zakho (HJUOZ)

Vol. 5, No. 2, pp. 496-501, June-2017

\title{
ZAKHO: A TOWN OF TOLERANCE AND COEXISTENCE IN ARIEL SABAR'S MY FATHER'S PARADISE
}

\author{
Khorsheed Mohammed Rasheed and Chiad Abdulsetar Abdulkarim \\ Department of English, Faculty of Humanities, University of Zakho, Kurdistan Region - Iraq.
}

(khorsheed.ahmed @uoz.edu.krd)

Received: 03. 2017 / Accepted: 05. 2017 / Published: 06. 2017

https://doi.org/10.26436/2017.5.2.399

\begin{abstract}
:
Despite the fact that Zakho provides a safe sheltering for multi-faith/ethnic groups, little has been documented about tolerance and coexistence regarding people residing this town. This paper analyzes a book titled My Father's Paradise, written by Ariel Sabar, published in 2008. It focuses on the initial events of the book that take place in Zakho; a town located in Kurdistan region of Iraq. This town plays an important role in the development of Sabar's main characters of the story. Additionally, the paper focuses on the notion of tolerance among various religious groups co-existing in the same town. In exploring the notions of tolerance and coexistence, researchers closely approach the development of major character in order to gain insights into characters' lifestyle and how they are represented in the world of the story. The paper concludes that the ambience of Zakho town, including cultural, traditional and geographical elements as well as personal names, have essentially influenced individuals' moral, intellectual, and spiritual character development of My Father's Paradise.
\end{abstract}

KEYWORDS: Tolerance, Coming of Age, Co-existence, Zakho, character development, Ariel Sabar.

\subsection{Instructions}

\section{INTRODUCTION}

During WWI, the town of Zakho and its sub-districts, like most Kurdish cities, were invaded by British forces. Rasheed Bag, the chieftain of Berwary tribe fled from his home village Dêrshesh to the city of Berman. There, he did not only enjoy his freedom, but commanded his local territorial army as well in regard to fighting back the British forces in the region. One day, Rasheed's Territorial Army arrested ten British Soldiers in the region. They took all ten of them as prisoners and headed to the city of Berman to meet with the chieftain. There, he generously treated them for few days. Then, he gave each one of them a set of Bargeez as a gift. After that, he sent a letter to the British headquarter in the town of Zakho, in it, he stated the release of prisoners unconditionally and set a specific date for the British forces in order to get there on time and embrace back all ten prisoners. Before the departure of prisoners, Rasheed told them "if you don't mind, today I want you to wear your Bargeez and then meet your combatant". They said "since you are going to release us without any conditions, we are going to gladly wear Kurdish Bargeez" When all ten prisoners got back safely to their headquarter in Zakho, British officers decided to exculpate Rasheed and his territorial army from the list of adversaries. They sent him an appreciation letter for his generosity and it stated that he can get back to his home village Dêrshesh safely at any time.

Some people may not realize that ethnic groups residing in the town of Zakho and its suburbs have kept their native language, religion, social practices for more than two thousand years. Major groups include Assyrian, Jewish, Yezidis, and most recently Armenians who migrated to this town in the Armenian Genocide. These groups kept their identity, religious icons and symbols, and even their traditional way of life throughout the ages. Although in other neighboring cities such groups have continuously suffered from intolerance, displacement, and genocide, it is in the town of Zakho and its suburbs that they have coexisted and enjoyed living a peaceful life. They have frequently flourished their business to other parts of the middle easternregions. As Donna Rifkind in her review puts it "when conquering Muslim armies imposed Arabic. By the 1930s, except in enclaves like Zakho, Aramaic as an everyday tongue was more or less extinct." (Rifkind, 2008). Rifkind positively comments the successful role Yona has played as a professor at the University of California, Los Angeles "where he has taught for three decades and where he composed a definitive Jewish-Aramaic dictionary," (Rifkind, 2008).

In exploring the notions of tolerance and coexistence, researchers have initially considered the story of Miryam and how she was brought up in the town of Zakho. Then, it is followed by the main analysis concerning the elements of coexistence as the book have demonstrated in its initial chapter.

\subsection{Historical Context}

Since the establishment of Iraq as a country and even prior to world war I, Zakho, a small town located in northern part of Kurdistan region of Iraq, has served mainly two functions: firstly, it bridged the three major parts of Kurdistan regarding trade. Secondly, it was sheltering people from a variety of faiths without imposing the belief of one group upon the other. The structure of the community in the town itself documents tolerance among its citizens as there are Christian residential blocks; Muslim's and Jewish streets are located side by side in the heart of the town.

Jewish community existed in many parts of Iraq, Zakho is one of the towns that has a great section of Jewish people who settled in a particular quarter in the center of town which is called Jewish Quarter (Mihela Cuhiya). Besides, many other families lived in different villages around the town. "Jewish people were business men and craftsmen who dominated the greatest part of the economy of the town and its Suburbs" (Alrezvani, 2009, p. 408). The community played a great role in various aspects of life, it focused on maintaining trade and crafting to be processed positively in the center of the town and its surroundings. Jewish people were considered to be smart enough by using their wit, being self-reliant, and their experiences, they could regulate and control the trade, industry, agriculture, including the practice of traditional medications such as curing diseases by herbal medicine and so on. Zakho was enriched by the existence of Jewish community and its well-crafted labours where they 
bulit a cmmercial bridge between zakho and Mosel city during the beginning of $20^{\text {th }}$ century. Apperantly, They transported Commercial convoys of props and woods from the mountains to the bank of Habur and then forwarded to Mosul city for the purpose of trade and house construction, thus, it had a great impact on the economy of Zakho town. Regarding the Jewish-Muslim relationships, both communities enjoyed living harmoniously in the same town. Their coexistence, neighborhood, brotherhood, and relations symbolized the peaceful life in which they shared tradition, culture, and social life. "There were no differences among ethnic minorities that led to state a clear history from any civil wars, problematic issues, or any quarrels and disharmony" (Al-Razvan, 2009, P. 408. On one hand, the communication, interaction and Interrelationship among familes were built strongly between Jewish and Muslim people at the personal and family levels. On the other hand, both Jewish and muslims didn't suffer from any major difficulties or complications. Jweish people in Zakho humbly participated in their neioghbors' fetivials and cermonies, they wore traditional dress as Kurdish ethnic dress while they were celebrating side by side with the Kurdish-Muslim people, particularly at the west of Habur river. Accordingly, both Jewish and Muslims were comfortably working, celebrating, worshiping in their own religions together in the same town, "Zakho is called as a (Qudis) Jerusalem of Kurdistan and sometimes it is called the Jerusalem of Jewish people" (Alrezvani, 2009, p. 409) . It is to be considered that Zakho town is a dvine town for Jewsih due to its value and significance in terms of religious edcation. Many of the priests and clergymen from different parts of iraq including Amadiya, Duhok and other sorroundings wrer visitinng Zakho for the purpose of education and religious learnings at the Jewish Synagoges.

Ahmed Al- Abasi Aljunaidi, a clergyman ( Mala) of Zakho's Great Mosque has declared in his speech on Friday, $10^{\text {th }} \mathrm{July}$, 1915 "Murdering Christian people is an oppression and contradiction, and it is a sin which can't be forgiven, moreover, to steal and prey Christian properties is strongly elicited and prohibited to you all". Aljunaidi is regarded as the prominent reason behind unifying Citizens of Zakho, particularly Muslims who started to protect Christian people who had immigrated from Bedar and other villages to Zakho due to the genocide of Nasara (Christian massacre) which took place in Turkey. A number of tribes in Sharnakh City attempted to ruin the Christian community. Zakho-Duhok Chaldean Bishopric declared in a letter of appreciation that the efforts of the preacher (Mala) and his enthusiastic speech to muslims at the Mosque led people to build a great shield for protecting Christian people from savage and primative attacks. Meanwhile, there were also many Christian immigrants residing in Zakho town before that incident, Zakho became a peaceful place for immigrants to hide and to be saved. In accordance with the letter itself, it dealt with the chaterstrophic events that Christian people faced in Turkey. It also, mentioned the role of Muslims community in protecting immigrants in Zakho. Muslims' attitudes towards immigrants was highly appreciated in the above mentioned letter.

A notably agha named Mohammed, is considered as one of the greatest leaders of a tribe in Zakho whose great support with his followers was respectedly appreciated by Zakho Chaldean Bishopric. "undoubtedly, by the support of Mohammed Agha and Zakho Citizens the Turkish plan of genocide failed in Zakho" (Alrezvani, 2009, p. 89)

After Turkish Government planned a huge military and political strategy for abolishing Armanin people in 1915 in all over the country, Armenian people faced various sorts of murdering and massacres. Many Armenian families fled and displaced to Iiraqi borders for survival. One more time,
Zakho town opened its wide hands of helps and supports for the immigrants to shelter them in thier own quarter ( Gondik). Based on the descriptions about the way of treatment and offering helps, Alrezvan concentrates in his book that the Zakhos' inner goodness where started helping them by providing foods and equipments for their needs. Armenians were safe and lived peacefully with Muslims, Jewish and Christian communities. "Although Zakho's people were living in a poverty and difficulties, but they welcomed them cordialy with well-treatment" (Alrezvani, 2009, p. 91). Armenian families had lived in coexistence and brotherhood in Zakho town. Armenians were settled down in a specific quarter which is so-called Armenians quarter, as Jewish and Christian quarters side by side of Muslim community. Geographically, it attempted to emphasize that zakho had given the right to all various religions and nations. In addition, there were no any sorts of discrimination, segregation, or even marginalization since no one could observe that one was more supperior and valuable than the other. Consequently, equality was covered since all of these communities worked cooperatively in terms of industry, trade, and agriculture, furthermore, they all were sharing cultural and traditional costumes and attitudes during celebrations and festivals, undoubtedly, each one followed their own particular faith, beliefs, and worshiping based on the order of thier religions.

Muslims well-treatment immigrants and provided security and safety for them. "A number of Christian people pretended to be Muslims in Turkey due to their insecure life and tyrannical domination, after feeling more secure, they turned to their own previous religion while they moved to Zakho. Then they didn't get threatened by any one in the society". (Alrezvani, 2009, p. 59)

\section{MY FATHER'S PARADISE AND THE NOTION OF TOLERANCE}

\subsection{Miryam's Character Development}

In the initial chapter, My Father's Paradise records the upbringing of Miryam from her early childhood, poor maternity conditions to her migration. Throughout her course of life, Miryam goes through difficult circumstances which make her character develop spiritually and morally. Also, As an individual, this section demonstrates certain facts about her upbringing from childhood to adulthood in the town of Zakho, without having been segregated or discriminated by her neighbors.

Miryam's first experience of coming of age is the lack of a compassionate mother. She was only 3 years old when her mother passed away. This marks a turning point in her life as a child. she took the moral responsibility of taking care of her little brother named Yusef. Later, she was raised up by her stepmother who doesn't try to make any sense of connection to her as a child.

Maturity and marriage life is a matter of surprise for Miryam, because her wedding was pre-arranged by her father. The author uses dramatic irony when her wedding takes place. In fictional literary works, dramatic irony functions as an element of suspense that bridges the multiple perspectives in the work and the audience, i.e., it foregrounds the relative reality in accordance with character's limitation. However, in non-fiction, and specifically in the instance of Miryam, the dramatic irony suggests how limited the relationship is between a father and her daughter. This instance informs the audience regarding the ritual of decision-making in the family. It represents the reality of Miryam in which she has no voice as a daughter regarding her future husband:

My stepmother is behind this, she though. She convinced my father to throw his own daughter out of his house. I wasn't a good enough servant for her. So she is putting me to work as a maid. A sob erupted inside her chest. Her father was several paces ahead of her now, but well within earshot. "Daddy," 
she gasped, she looked searchingly after him, waiting for him to turn around, to see her tears. His head twitched as though at noting more vexing than a fly's buzz. Then he vanished through the crooked timber door frame...Miryam felt sick at the at the dawning reality of what was happening. She had been summoned here not as a servant but as a bride. (Sabar, 2008, pp. 26-28)

The struggle she goes through with her stepmother becomes apparent in her teenage years. As a reader, one can understand that Miryam is not going to be a servant in the family of Beh Sabagha, but she is going there for engagement reasons. Without her knowledge, this event has been arranged by the heads of both Miryam and Rahamim's families. However, for Miryam as a daughter, this event initially would rather make her doubt her father's care toward her. This misunderstanding would continue for generations to come. It was not an easy task for Ariel himself to understand his father and write down this book regarding his father's displacement and long journey. Miriyam Glazer creates vivid images of the contrastive places where Yona and his son raised up. Yona's is described as an isolated place that has no electricity and depended on traditional ways of life while Ariel lived "on a leafy street guarded by private police cruisers" (Glazer, 2010). Glazer's also deals with the sense of belonging, as for Yona's parents, the new place is displacement while for the younger generation it has a different story. "While Yona's parents, Ariel's grandparents, experienced a great sense of loss, displacement, disappointments, and sorrow over the years, Yona himself, through unremitting hard work and sheer brilliance, after completing his army service became a student at the Hebrew University of Jerusalem." (Glazer, 2010).

Also, maturity for Miryam is about being a strong baby sitter which makes her religious faith grow stronger. Miryam has lost her first child, she does her best to raise up a healthy child in her second conception. As a result, she pays a visit to the holy shrine of Yona in the city of Mosul and she desperately prays so that she could give birth to a strong child. "'All I ask, dear prophet, 'Miryam whispered, 'is for a healthy baby in my belly. A baby no better or worse than the other strong children of Zakho." (Sabar, 2008, p. 46). In this regard, Miryam's religious indoctrination grows while she goes to the city of Mosul accompanied by her husband. This journey marks an important event in her life regarding her spiritual growth. First she learns the story of Yona as it is indicated in her journey "Miryam had asked her husband to tell her the whole story on the bust rider there." (Sabar, 2008, p. 46). Secondly, her religious faith grows stronger as we will realize ten months later, between the year 1938 and 1939, that she has given birth to a boy named after Yona. When Yona grows up and starts going to school, his mother wakes him up and sends him to the synagogue also, so he could join his grandfather Ephraim and practice his religious belief.

In addition to the religious growth Miryam goes through, she shows moral growth as well. For Miryam, being a good housewife means having few children. After having raised up Yona as a healthy child, Miryam considers it as a moral duty to raise up more children. Although she gave birth to five more children, however, all of them died. As a result, she becomes a devoted mother to her only child Yona. She called him "Kurbanokh", which means she is ready to sacrifice herself for the cause of her only son. From her attitude toward child upbringing, it becomes clear that she considers it as a moral duty to raise up more children. But it is due to the ill fate that few of her children suffered from stillbirth as it is indicated, while others passed away from diseases. "Miryam would bury three boys and two girls in Zakho. Several were stillborn, the others died of disease. Only one - a girl named
Fawziya - lived long enough to be given a name." (Sabar, 2008, p. 20).

What remains interesting in the initial chapters of the book is to note how young Miryam is able to accommodate with the expectations that are put upon her. Her father made the decision regarding her future husband, and she doesn't show her impression regarding this decision. Her story is representative of many other stories as Alex Ramington puts it:

Through his family's story, Sabar manages to bring to life a community of a few thousand Jews who lived almost beyond the world's ken. Then he enters the fray, as he tries to track down a few loose ends, see his father's homeland for himself and search for his missing great-aunt, and finds himself frustrated by the past. (Ramington, 2010)

The book have foregrounded the story of a man who represented many Jewish people living in a small city. This was a common practice by many Kurds who lived in that era as well as it was the case of Miryam. Her character development is dependent on her husband and her family members as it is the case of most Kurdish housewives. For Miryam, group work is necessary for survival of the family.

\subsection{Coexistence as Represented in Sabar's My Father's} Paradise

Tolerance, a key to coexistence, is represented in this work as a social practice in the town of Zakho as well as a major theme of the book. The notion of Tolerance is directly related to the initial setting of the work in which it is sensed as a homeland for Yona. Although the work rarely portrays some degree of none-tolerance being practiced by the Iraqi government and Iraqi people in few Major Iraqi cities and towns, it is Zakho where religious and cultural tolerance prevails.

As a minority faith, Judaism has been practiced by the Jewish community in the town of Zakho for more than two thousand years. In reviewing My Father's Paradise, Hara Person states that "Sabar explores what life was like for the Kurdistani Jews, creating a detailed picture of a rich and peaceful coexistence with non-Jewish neighbors" (Person, n.d.). The survival of their Aramaic language, religion, and culture suggest that they have enjoyed a certain degree of tolerance along the way while residing in Zakho. As a matter of fact, they were not the only minority living in the town of Zakho, Christians, Armenians and Yezidi people living in the vicinity of the town have, also, preserved their rituals without facing any major obstacles by their Muslim neighborhoods residing in the town. Although it is noted that Muslims are the dominant group in Zakho. But as it has been documented in My Father's Paradise, as long as other ethnic groups paid their share of taxes, they continued doing their business peacefully "So long as Jews paid taxes and gave lip service to the supremacy of Islam, they continued to enjoy broad freedoms of trade and religious. The climate of tolerance survived the rise and fall of empires, and in 1908 the Ottoman rulers put it in writing with the constitution granting equal rights to non-Muslims." (Sabar, 2008, p. 62).

Ultimately, what led Jewish community to migrate from Zakho to Israel, is the Iraqi government policy which can't be tolerated anymore. They committed atrocities against minor ethnic groups in other cities and remote areas. Such events instilled fear in ethnic groups in cities even unaffected. It is mentioned that in the year 1932, Iraq has agreed to protect the rights of its minorities in the league of nations. But in 1933, Iraqi government started committing atrocities against Assyrian minority "Iraqi troops massacred three thousand Assyrians, Aramaic-speaking Christians with ancient roots in northern Iraq." (Sabar, 2008, p. 61). The only reason for committing atrocities was that "The Assyrian had been seeking broader political rights, and a group of eight hundred had taken up arms." (Sabar, 2008, p. 62). This policy of 
burning houses of villagers in remote areas and razing the town of minorities has been practiced by Succession Iraqi governments one after another. They did this against Kurds in General, no matter who the inhabitants of the villages or towns were. A recent instant would be the year 1979 in which the Iraqi government razed 75 villages in the Brewery region only. Also, in Guli, Sindi regions tenth of villages were razed and their residents were displaced as far as Ramadi, Baghdad, Basra and some of them were obliged to escape to the neighboring countries such as Iran, Turkey, and even some of them ended up in European and American diaspora.

\subsection{Language of My Father's Paradise}

In general, a literary text, fictional or non-fictional, has a unified language. But Sabar's book is written in English and has many foreign words. Kurdish words and themes are predominantly used to deal with the relationship between his main characters and the Kurdish society in Zakho. More importantly, Sabar attempts to create a shared world of multilingual, multi-religious, and multi-national citizens where Zakho is symbolized as a land of tolerance. Gal Beckerman comments on the book as being "part history, linguistic primer and memoir." (2008). Generally, he highlights a point to define the people as tolerant as possible, as he defines the area, "In Kurdistan, religions from Islam, Christianity, and Judaism to Sufi mysticism, Bahaism, and Yezidism flourished alongside one another, and extremism was rare" (Sabar, 2008, p. 69). Through Sabar's language of his book many Kurdish sings and symbols are clearly identified by the reader. Consequently, making use of Kurdish cultural and traditional elements along with the different words and names will automatically justify the Kurdish-multinational and religious shared relationships in a specific town.

\subsection{Kurdish Sensibility in the Language of My Father's Paradise}

In our endeavor to explore the notion of Kurdish sensibility, researchers have mainly depended on the definition of sensibility given by the Belford Glossary of Critical and Literary Terms, particularly, the second part regarding modern day works which states "Sensibility has a second application in modern critical discourse, one referring to the inherent nature or quality of an individual's sensitivity (both intellectual and emotional) to aesthetics and sensory experience.” (Murfing \& Ray, 2003, p. 439)

Basically, writings in English, as in various languages, have its own features and characteristics that enable the reader to have an understanding or ability to identify the origins of text so easily. Most of the writers knowingly or unknowingly make use of several aspects including names, cultural and traditional elements, and themes in literary texts which are written in different languages, particularly in English. Accordingly, one could directly determine that the actual text belongs to a specific society or a conclusive ethnic-group. Sabar's My Father's Paradise is clearly one of the highlighted texts which consists of mutual elements shared by Kurdish writings in English. Due to the use of Kurdish words including names of the characters, places, Kurdish cultural and traditional elements, the book cannot be ignored from the perspective of Kurdish sensibility written in English language. The major elements and words used in Sabar's $M y$ Father's Paradise are divided into three main categories:

\section{Cultural Elements}

Culture, as defined by the Bedford Glossary of Critical and literary terms "examine how literature emerges from, influences and competes with other forms of discourse (such as religion, science, or advertising) within a given culture. They analyze the social contexts in which a given text was written and under what conditions it was-and is-produced, disseminated, and read." (p.80). In accordance with this definition, it is not the high or low culture that the researchers are interested in, but rather shared cultural elements that unify ethnic groups of the same community, as Sabar's book describing the arrangement of weddings and engagements by gathering women while they were singing delightfully "The room rang with a song Maryam had heard at her cousin's betrothal ceremony" (Sabar, 2008, p. 28).

Arial Sabar uses numerous Kurdish cultural words and elements that can be considered as shared elements between both Jewish and Muslim community in Zakho. Besides, there are certain mutual features and characteristics that are shared throughout various festivals and ceremonies in which are presented in both societies. Siso (2016) in her MA thesis concludes that the shared Cultural traditions among nations could produce social representation "The Kurdish and Kurdish Jewish social identity is the outcome of their shared traditions" (Siso, 2016, p. 80). In weddings, both communities used enthusiastic way of expressing happiness that it is shared and specified by uttering expressions, as Sabar is depicting the wedding ceremony through different Kurdish expressive words for happiness "the women raised a ululation that could be heard half way down the street "Klilililililili, Klilililililili" (Sabar, 2008, p. 27). Meanwhile, in social norms and customs, both are using the same path to be protected as it is clear from the dialogue between Characters in the book "God saved my son' Yona's father said, "by sacrificing a cow" the man in the Coat said. (Sabar, 2008, p. 19).

Sabar illustrated, in his My Father's Paradise, the shared ritual process of protecting child from any mischievous things while children faced mental problems. "The relative would then hire the mother to nurse and raise the baby, a ruse to confound the jinne - the demons - and protect the child" (Sabar, 2008, p. 20). The book focuses on the cultural interrelation between Jewish and Muslim communities. It demonstrates the shared elements that both sided did during their lives. Furthermore, both communities shared the same rituals in running funeral ceremonies, for instance, dirges and hymns were sung to dead bodies during the funeral.

\section{Traditional Elements}

Throughout reading Sabar's My father's Paradise, the reader can identify a number of Kurdish traditional items and elements that enabled the authentic image of Kurdish society to be mirrored in 1940s. The most popular traditional dress's name was mentioned by the author in his book is " a short man in a shalla u-shappiksa of such brightly colored stripes" (Sabar, 2008, p. 16), "his grandfather dipped sherwals and shalla u- shappiksas into drums of dye." (Sabar, 2008, p. 27). The book picturizes the real image of Kurds and it illustrates that Jewish community was experienced in wearing the same dress in which it is remarkably a part of Kurdish traditional clothing style. Sabar attempts to select the dress of high class in Kurdish society. In addition, the book deals with Kurdish traditional food items that symbolize the citizen's favorite foods during early decades of $20^{\text {th }}$ century in Zakho such as "Yaprach, Yaprach" they would chant" (Sabar, 2008), "Kaimach" ( p:19), and "form the saucerlike dumplings called Kubeh" (Sabar, 2008, p. 23) , Thus, it can be inferred that these sorts of foods might be shared more commonly by Jewish, Muslim and even Christian community In Zakho.

\section{Geographical and Personal Names}

The setting of Sabar's My Father's Paradise is an important sign to justify the Kurdish sensibility which is Zakho town during the beginning of the $20^{\text {th }}$ century where the story of his main characters takes place. This book draws attention of the readers to identify that the book itself is going to deal with the issues related to the Kurdish society. Through description of Jewish community through major characters, Sabar shows the shared spots that usually combine Jewish people where they meet their neighbors, either Muslims or Christians, as the book states names of some areas "and men at the Chaykhana sipped glasses of tea" (Sabar, 2008, p. 15). It 
makes the setting of the story more recognizable. In addition, the name of the river beside the town and the description of the houses give one more geographical justification that the story takes place in Zakho which belongs to Kurdish society, "Their mud-brick houses lines narrow alleys that zigzagged down to the Habur River" (Sabar, 2008, p. 15). The most specific Kurdish name of a part of a house that My Father's Paradise informed which is mostly related to Kurdish community is "Birbanke" which was propped up by a row of wooden posts. Moreover, the book covers several names that show the interaction between both societies such as Abdulkarim Agha who helped Jewish people while they got in troubles, as well as, some Muslim characters as Naze and Haji, In addition, the names of the most popular tribes as they are mentioned in the book" the supreme power of the region's Sindi, Guli, and Slivani tribes" (Sabar, 2008, p. 33), it shows socio-historical relationship among various multi-religious communities. These names played a great role in the lives of Jewish people as it is quietly argued by the author in his book. Consequently, Sabar's Kurdish - English language helps the reader to better understand and widely expand the knowledge regarding the context and themes of Kurdish community. Readers would easily recognize by their power of senses and sensibility that My Father's paradise argues the issues of Kurdish and Iraqi Jewish people in Zakho as an essential location. Geographical evidence for coexistence "stone and Suspension Bridge linked the island to Muslim" (Sabar, 2008, p. 15).

\section{CONCLUSION}

Understanding one another humanly, leads to the construction of communities where basic rights of different ethnic groups constituting societies such as language, culture, practice of beliefs are preserved for a very long time. This has been documented in My Father's Paradise. Miryam, being the main focus of the initial chapter of the book, represents the Kurdish woman in community in a wider spectrum during the first few decades of the $20^{\text {th }}$ century. She has suffered the loss of few of her children, but she developed communal skills and raised up a healthy child named Yona who represented Jewish community in Kurdistan in general and specifically in Zakho. It is through Yona that a historical context of coexistence is brought to light.

Zakho had included various communities includig Jewish, Muslims, Christian, and Armenian without any discriminations based on race, ethnic, sects, or religion. More importantly, the role of Citezens and several leaders from Zakho including Mohammed Agha and Ahmed Al- Abasi Aljunaidi, a clergyman (Mala) of Zakho's Great Mosque played an important role concerning providing safety for immigrants. Accordingly, Zakho has been definied as a town of peaceful living for its constituents. It is remarkable that even today the people of Zakho, as it has been the setting of coexistence in My Father's Paradise, remain believing it is a town of survivors, supporter of immigrants, and it continues sheltering displaced people with arms opened widely to welcome people from its neiboring dusputed areas.

There are many mutual cultural elemenst among inhabitants of Zakho that is shared by different ethnic groups which enable a society to live cooperatively and equaly at the same time. These elements create a multi-ethnic and multi-religious community in Zakho even today where Churches, Mosques and temples still exist.

\section{REFERENCES}

Alrezvani, S. (2009). Zakho In the Past and Present (Zakho Almazi we Alhazir) (Second ed.). Duhok.

Beckerman, G. (2008, October 9). Ariel Sabar's 'My Father's Paradise', digital. Retrieved Novembr 11, 2016, from The New York Times: http://www.nytimes.com/2008/10/12/arts/12ihtidbriefs11C.16821028.html

Glazer, M. (2010). MY FATHER'S PARADISE BY ARIEL SABAR. Retrieved November 17, 2016, from American Jewish University: http://library.aju.edu/Default.aspx $? i d=3457$

Murfing, R., \& Ray, S. M. (2003). The Bedford Glossary of Critical and Literary Terms (Second ed.). New York: Bedford/St. Martin's.

Person, H. E. (n.d.). My Father's Paradise: A Son's Search for his Jewish Past in Kurdish Iraq, Digital. Retrieved November 16, 2016, from Jewish Book Council: http://www.jewishbookcouncil.org/book/my-fathersparadise-a-sons-search-for-his-jewish-past-inkurdish-iraq

Ramington, A. (2010, March 18). My Father's Paradise: A Memoir About a Lost Jewish World, digital. Retrieved November 16, 2016, from The Huffington Post: $\quad$ http://www.huffingtonpost.com/alexremington/my-fathers-paradise-amem_b_361686.html

Rifkind, D. (2008, October 26). My Father's Paradise: A Son's Search for his Jewish Past in Kurdish Iraq, Digital. Retrieved November 17, 2016, from Washington http://www.washingtonpost.com/wpdyn/content/article/2008/10/23/AR2008102302573.ht $\mathrm{ml}$

Sabar, A. (2008). My Father's Paradise. Chapel Hill: Algonquin Books of Chapel Hill.

Siso, M. P. (2016, October). Culture and Identity in Gharbi Mustafa's When Mountains Weep and Ariel Sabar's My Father's Paradise (Unpublished master's thesis). Zakho, Kurdistan Region of Iraq: University of Zakho. 


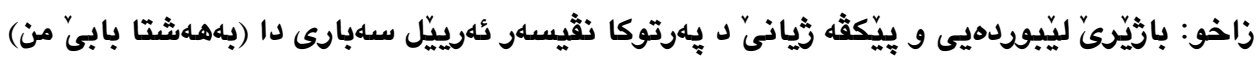

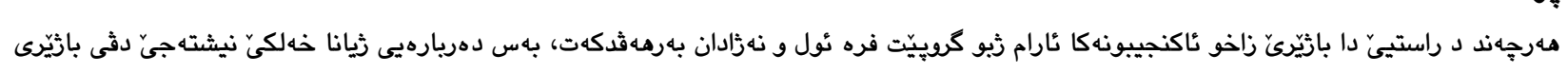

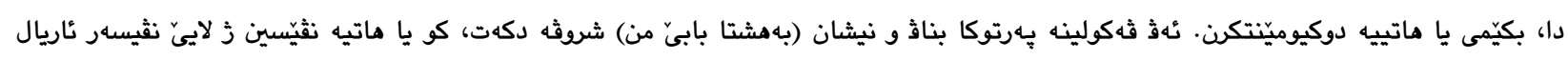

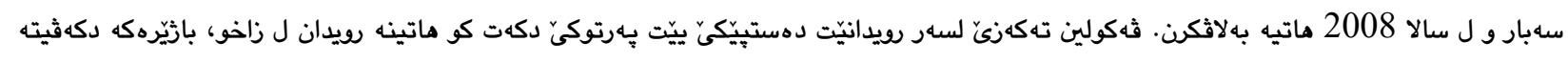

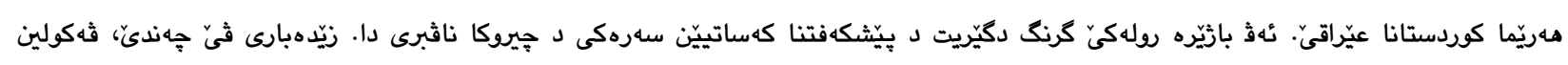

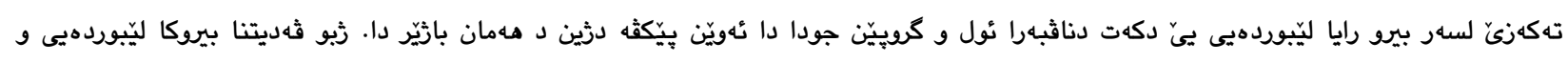

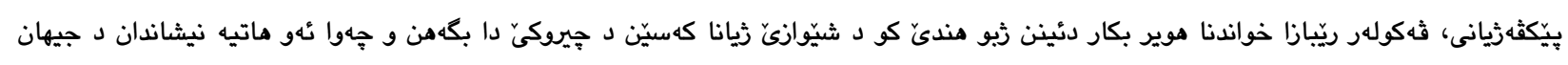

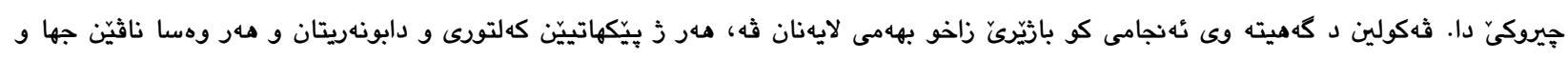

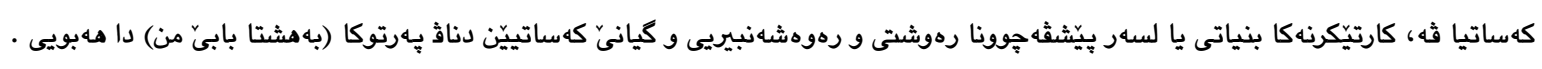

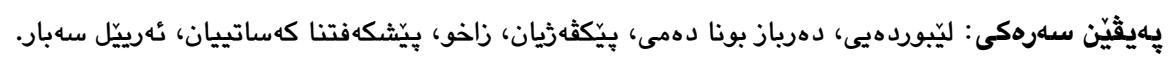

\section{زاخو: مدينة التسامح و التعايش في كتاب جنة ابي للكاتب اريل صبار}

الخلاصة:

بالرغم من ان مدينة زاخو تشكل ايواءاً امناً للمجاميع الدينية والعرقية المختلفة الا ان القليل قد وثق فيما يتعلق بمفهوم التسامح و التعايش في المدينة. يقدم

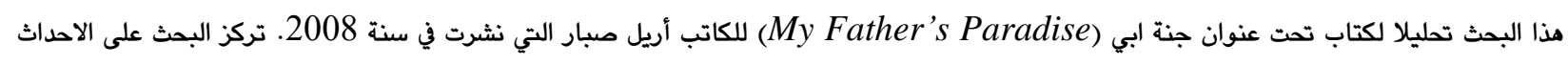

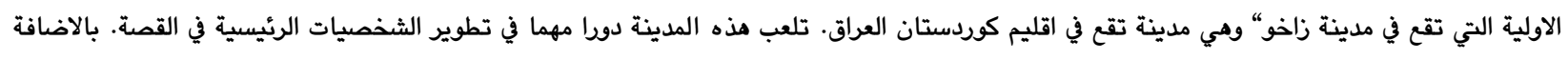

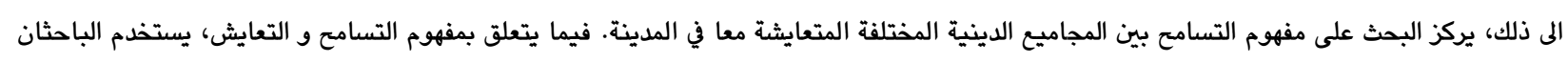

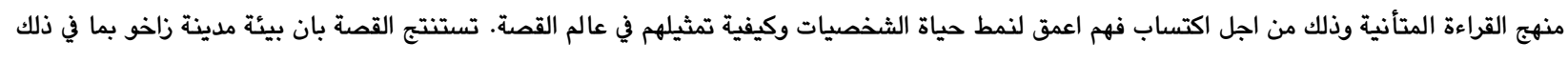

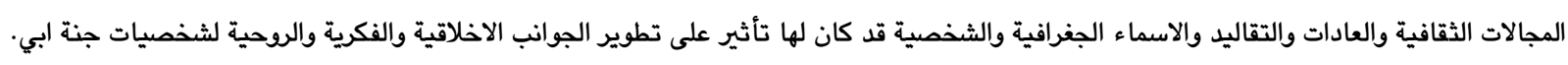
الكلمات الدالة: التسامح، التعايش، زاخو، تطوير الشخصيات، أربل صبار. 